\title{
Reference gene selection for quantitative reverse transcription-polymerase chain reaction normalization during in vitro adventitious rooting in Eucalyptus globulus Labill
}

Márcia R de Almeida ${ }^{1}$, Carolina M Ruedell ${ }^{2}$, Felipe K Ricachenevsky ${ }^{1}$, Raul A Sperotto ${ }^{1}$, Giancarlo Pasquali ${ }^{1}$, Arthur G Fett-Neto ${ }^{1,2^{*}}$

\begin{abstract}
Background: Eucalyptus globulus and its hybrids are very important for the cellulose and paper industry mainly due to their low lignin content and frost resistance. However, rooting of cuttings of this species is recalcitrant and exogenous auxin application is often necessary for good root development. To date one of the most accurate methods available for gene expression analysis is quantitative reverse transcription-polymerase chain reaction (qPCR); however, reliable use of this technique requires reference genes for normalization. There is no single reference gene that can be regarded as universal for all experiments and biological materials. Thus, the identification of reliable reference genes must be done for every species and experimental approach. The present study aimed at identifying suitable control genes for normalization of gene expression associated with adventitious rooting in E. globulus microcuttings.

Results: By the use of two distinct algorithms, geNorm and NormFinder, we have assessed gene expression stability of eleven candidate reference genes in E. globulus: 18S, ACT2, EF2, EUC12, H2B, IDH, SAND, TIP41, TUA, UBI and 33380. The candidate reference genes were evaluated in microccuttings rooted in vitro, in presence or absence of auxin, along six time-points spanning the process of adventitious rooting. Overall, the stability profiles of these genes determined with each one of the algorithms were very similar. Slight differences were observed in the most stable pair of genes indicated by each program: IDH and SAND for geNorm, and H2B and TUA for NormFinder. Both programs indentified $U B \mathrm{~B}$ and $18 \mathrm{~S}$ as the most variable genes. To validate these results and select the most suitable reference genes, the expression profile of the ARGONAUTE1 gene was evaluated in relation to the most stable candidate genes indicated by each algorithm.

Conclusion: Our study showed that expression stability varied between putative reference genes tested in $E$. globulus. Based on the $A G O 1$ relative expression profile obtained using the genes suggested by the algorithms, $H 2 B$ and TUA were considered as the most suitable reference genes for expression studies in $E$. globulus adventitious rooting. UBI and 185 were unsuitable for use as controls in $\mathrm{GPCR}$ related to this process. These findings will enable more accurate and reliable normalization of qPCR results for gene expression studies in this economically important woody plant, particularly related to rooting and clonal propagation.
\end{abstract}

\footnotetext{
* Correspondence: fettneto@cbiot.ufrgs.br

${ }^{1}$ Center for Biotechnology, Federal University of Rio Grande do Sul, P.O. Box

15005, 91501-970 Porto Alegre, RS, Brazil

Full list of author information is available at the end of the article
} 


\section{Background}

Eucalyptus sp. is one of the most planted hardwood genus in the world [1], mainly because of its applications for generating wood and paper products. Brazil is the largest world producer of eucalypts for short fiber pulp [2], thanks to clonal forests developed from elite material with high productivity [3]. In southern Brazil and temperate areas, especially Mediterranean Europe, Portugal and Chile, Eucalyptus globulus and its hybrids are of interest for the cellulose industry due to their relatively high frost resistance and low lignin content, which facilitates cellulose extraction [4]. On the other hand, E. globulus is generally considered recalcitrant to rooting $[5,6]$. The commercial eucalypt forests are generally formed through vegetative propagation which has adventitious rooting as a key step [7]. This developmental process can be divided in two main steps, each with its own requirements and characteristics: (1) induction step, which involves biochemical and molecular events, without visible morphological changes; and (2) formation step, which consists of cellular divisions involved in both root meristem organization and primordium establishment, followed by root elongation and emergence out of the cutting [8].

Multiple factors can interfere with adventitious rooting, such as phytohormones, phenolic compounds, nutritional conditions and genetic characteristics [9]. Among phytohormones, auxins play a central role in rooting capacity [10], particularly its endogenous content and transport rate [11]. However, concentrations that are beneficial to root induction can block its elongation [7]. The shoot apex is the main source of endogenous auxin. Stems have a specific basipetal active transport through vascular parenchyma carried out by both influx (AUX1) and efflux (PIN) carriers [12,13].

Eucalyptus globulus needs exogenous auxin application for an adequate root development in vitro [8], but it is unknown if this occurs because of defficiencies in auxin content, transport or perception mechanisms, or due to some other non-auxin related reason that can block spontaneous rooting responses. At gene expression level, little is known about the formation of root meristems in woody plants and even less concerning the effect of auxins on this process [14].

To evaluate changes in gene expression, reverse-transcription followed by quantitative, real-time polymerase chain reaction (qPCR) is one of the most widely used methods. Some of the advantages of qPCR are high sensitivity and specificity, speed, ease of use and capacity to carry out simultaneous measurements of gene expression in several different samples for a limited number of genes [15-17]. To accurately and reproducibly quantify gene expression, some factors should be taken into account, such as quality and amount of starting material, presence of inhibitors in different samples, primer design, RNA extraction and reverse-transcription efficiencies [16]. Therefore, selection of an appropriate normalization strategy is essential for obtaining an accurate and reliable quantification of gene expression levels $[15,16,18]$. The most commonly applied approach for normalization of qPCR is the use of one or more endogenous reference genes [18-20], which will undergo the same type of variation and preparation steps throughout the assay as the target genes.

An ideal reference gene, also known as housekeeping or internal control gene, is assumed to be constitutive, $i$. e., it should be expressed at a constant level in the majority of the study organism cells, through different developmental stages and in different organs. Besides, its expression is assumed to be unaffected by experimental parameters [21]. Genes involved in basic cellular processes, such as cell structure maintenance or primary metabolism, are often chosen as normalizers [22]. However, the transcript levels of these putative reference genes are not always stable and their systematic use without previous validation may lead to the misinterpretation of results. Indeed, the previous assurance of at least one stable gene expression in all variable situations tested is recommended to accurately validate the expression of genes under analysis [22-27]. In recent years, a large number of reference gene validation attempts have been reported for plants, but most of them have covered model and crop species: rice [28,29], sugarcane [30], Arabidopsis thaliana [22,31], potato [26], grape [32], barley [33], Brachypodium sp. [34], soybean [35,36], tomato [37], Brachiaria sp. [38], coffee [39], peach [40], wheat [41], chicory [42], cotton [43], cucumber [44], longan tree [45], Petunia sp. [46], ryegrass [47], rapeseed [48] and tobacco [49]. Just a few studies have focused on forest genera, such as poplar [25,27] and Eucalyptus sp. [50]; however, there is a lack of investigations covering in vitro growth or adventitious rooting.

The aim of this study was to evaluate the stability of 11 putative reference genes for the purpose of normalization in studying $E$. globulus gene expression during in vitro adventitious rooting (Figure 1). Statistical methods implemented in geNorm [24] and NormFinder [51] were used and compared in this evaluation. In addition, to further validate the reference genes, an expression analysis of a putative E. globulus orthologue of the A. thaliana ARGONAUTE1 (AGO1) gene during rooting of microcuttings was carried out.

\section{Results}

To identify the most stable genes in E. globulus microcuttings rooted in vitro, we selected 11 candidate reference 


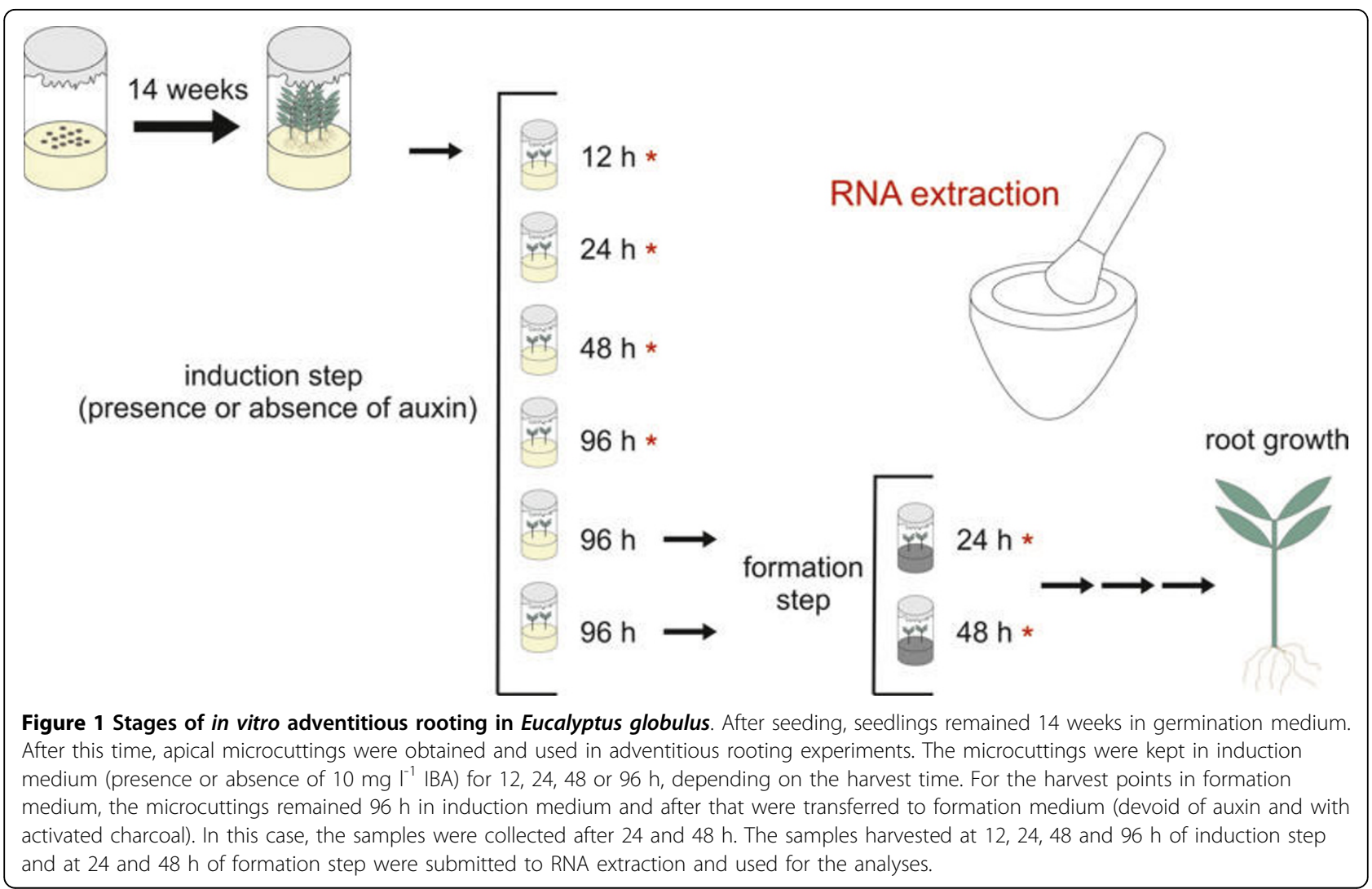

genes to validate by qPCR. The gene expression stability of the candidates was evaluated in a set of 12 samples covering six different stages along adventitious rooting time in the presence or absence of the phytohormone auxin. The genes included: $18 \mathrm{~S}$ ribosomal RNA (18S) [25-27,40], Actin 2/7 (ACT2) [24,40], Translation elongation factor 2 (EF2) [40], Histone H2B (H2B) [52], NADP Isocitrate Dehydrogenase $(I D H)$ [53-55], Polyubiquitin (UBI) [25,27], SAND protein $(S A N D)$ [22,31], TIP41-like protein (TIP41) [22,27,31,37], Alpha-tubulin (TUA) [25], an Eucalyptus ortholog of Arabidopsis thaliana expressed protein without determined function (33380) [22,27,31], and a putative RNA binding protein (EUC12) previously shown to be constitutive in different Eucalyptus organs (unpublished results). The characteristics of each of the listed genes, such as gene name, A. thaliana ortholog locus, A. thaliana locus description, GenBank accession number, function and E-value are provided in Table 1. All Arabidopsis genes were used simply to identify the corresponding orthologs in Eucalyptus using the Genolyptus project data base. The specificity of the amplifications was confirmed by the presence of a single band of expected size for each primer pair in agarose gel electrophoresis after PCRs employing either cDNA or chromosomal DNA as templates, and by the observation of single-peak melting curves of the qPCR products (data not shown). No primer dimers or other products resulted from non-specific amplification. Amplification efficiencies of PCRs ranged from 1.790 for $E F 2$ to 1.972 for $H 2 B$ (Table 2).

\section{Expression levels of reference gene candidates}

Not surprisingly, some variations on $\mathrm{Cq}$ values, i.e. number of cycles needed for the amplification-related fluorescence to reach a specific threshold level of detection, occurred among the reference genes tested. Transcripts of $18 \mathrm{~S}$ were the most abundant (mean $\mathrm{Cq}=$ $12.48 \pm 1.87$ ), followed by $H 2 B, 33380, A C T 2, I D H, U B I$, TUA, TIP41, EF2 and SAND, whereas EUC12 was the least abundant (mean $\mathrm{Cq}=25.30 \pm 0.63$ ) (Figure $2 \mathrm{~A}$ ). The expression profiles of all candidate reference genes along the adventitious rooting process are depicted in Figure 2B.

\section{Expression stability of reference gene candidates}

Two programs were used to evaluate the stability of the 11 candidate reference genes: geNorm [24] and NormFinder [52]. Cq data were collected for all samples and transformed to relative quantities using the delta-Cq method developed by Livak and Schmittgen [56] (see Material and Methods section for details). 
Table 1 Description of reference genes used for qPCR in Eucalyptus globulus

\begin{tabular}{|c|c|c|c|c|c|c|}
\hline $\begin{array}{l}\text { Gene } \\
\text { symbol }\end{array}$ & Gene name & $\begin{array}{l}\text { Arabidopsis } \\
\text { thaliana's } \\
\text { best hit } \\
\text { locus }\end{array}$ & $\begin{array}{l}\text { Arabidopsis thaliana } \\
\text { locus description }\end{array}$ & $\begin{array}{l}\text { Putative E. globulus } \\
\text { orthologs GeneBank } \\
\text { accession number }\end{array}$ & Function & $\begin{array}{l}\text { E-value } \\
\text { (tblastx) }\end{array}$ \\
\hline 185 & $\begin{array}{l}\text { RNA ribosomal } \\
18 \mathrm{~S}\end{array}$ & At3g41768 & RNA ribosomal $18 \mathrm{~S}$ & $\mathrm{HO} 048251$ & $\begin{array}{l}\text { Cytosolic small ribosomal subunit, } \\
\text { translation }\end{array}$ & 0,0 \\
\hline ACT2 & Actin $2 / 7$ & At5g09810 & Actin $2 / 7$ & $\mathrm{HO} 048249$ & Structural constituent of cytoskeleton & 0,0 \\
\hline EF2 & $\begin{array}{l}\text { Translation } \\
\text { elongation } \\
\text { factor } 2\end{array}$ & At1g56070 & $\begin{array}{l}\text { Translation elongation } \\
\text { factor } 2 \text {, putative }\end{array}$ & $\mathrm{HO} 048253$ & $\begin{array}{l}\text { Translation factor activity, nucleic acid } \\
\text { binding }\end{array}$ & $e-176$ \\
\hline EUC12 & $\begin{array}{l}\text { Putative RNA } \\
\text { bindig protein }\end{array}$ & * & * & $\mathrm{HO} 048248$ & Unknown & e-78 \\
\hline$H 2 B$ & Histone $\mathrm{H} 2 \mathrm{~B}$ & At5g59910 & Histone $\mathrm{H} 2 \mathrm{~B}$, putative & $\mathrm{HO} 048243$ & $\begin{array}{l}\text { Strutural constituent of the eukaryotic } \\
\text { nucleosome core }\end{array}$ & e-66 \\
\hline$I D H$ & $\begin{array}{c}\text { NADP- } \\
\text { Isocitrate } \\
\text { dehydrogenase }\end{array}$ & ** & ** & $\mathrm{HO} 048252$ & Carbohydrate metabolism & ** \\
\hline$U B I$ & Polyubiquitin & At4g05050 & $\begin{array}{c}\text { Polyubiquitin gene, } \\
\text { belongs to a subtype } \\
\text { group with UBQ10 and } \\
\text { UBQ14 }\end{array}$ & $\mathrm{HO} 048245$ & $\begin{array}{l}\text { Signalling complexes for protein } \\
\text { degradation, translation control, DNA } \\
\text { repair, endocytosis regulation, protein } \\
\text { traffic }\end{array}$ & $e-144$ \\
\hline SAND & SAND protein & At2g28390 & SAND family protein & $\mathrm{HO} 048246$ & $\begin{array}{l}\text { Intracellular vesicular transport, biogenesis } \\
\text { and vacuole signalling }\end{array}$ & $e-68$ \\
\hline TIP41 & $\begin{array}{l}\text { TIP41-like } \\
\text { protein }\end{array}$ & At4g34270 & TIP41-like family protein & $\mathrm{HO} 048247$ & Unknown & e-78 \\
\hline TUA & Alpha-tubulin & At5g19780 & Alpha tubulin-5 & $\mathrm{HO} 048250$ & $\begin{array}{l}\text { Structural constituent of cytoskeleton, } \\
\text { microtubule-based processes }\end{array}$ & e-134 \\
\hline 33380 & $\begin{array}{l}\text { Expressed } \\
\text { protein }\end{array}$ & At4g33380 & Expressed sequence & $\mathrm{HO} 048244$ & Unknown & e-74 \\
\hline
\end{tabular}

* Gene assumed as constitutive in microarray studies employing leaf and vascular tissues of fully grown E. globulus and E. grandis trees (unpublished results).

** Gene obtained from Carvalho et al. (2008) [55].

\section{geNorm analysis}

The average expression stability ( $M$ value) of all genes was calculated by geNorm (version 3.5). The $M$ value is defined as the average pairwise variation of a particular gene with all other potential reference genes. The average $M$ values of the candidate reference genes tested are shown in Figure 3 and summarized in Table 3. The geNorm program recommends using an $M$ value below the threshold of 1.5 to identify reference genes with stable expression, but some authors propose the maximum value of 0.5 to obtain more accurate results [57,27]. Our results indicate $I D H$ and $S A N D$ as the most stably expressed genes (i. e., with the lowest $M$ value $=0.320$ ) and $18 S$ as the least $(M$ value $=0.935)$. To evaluate the optimal number of reference genes for reliable normalization, geNorm calculates the pairwise variation $\mathrm{V}_{n} / \mathrm{V}_{n+1}$ between the sequential ranked normalization factors $\mathrm{NF}_{n}$ and $\mathrm{NF}_{n+1}$ to determine the effect of adding the next reference gene in normalization. The normalization factor is calculated based on the geometric average among the three most stable genes relative quantities and stepwise inclusion of the other genes in the order of their expression stability. A large pairwise variation implies that the added reference gene has a significant effect on normalization and should be included for calculation of a reliable normalization factor [24]. Considering the cut-off value of 0.15 proposed by Vandesompele et al. [24], below which the inclusion of an additional reference gene is not necessary, the use of the two most stably expressed genes (IDH and SAND) is sufficient for accurate normalization $\left(\mathrm{V}_{2 / 3}=0.107\right)$ in $E$. globulus in vitro rooting (Figure 4). If needed, the EUC12 gene can be added to the analysis, resulting in a pairwise variation value of $0.087\left(\mathrm{~V}_{3 / 4}=0.087\right)$ (Figure 4).

\section{NormFinder analysis}

In addition to the analysis by the geNorm software, the expression stability of the candidate reference genes on the experimental samples was also evaluated by NormFinder. This program takes into account the intra- and inter-group variations for normalization factor calculation and the results are not affected by occasional coregulated genes. The best candidate will be the one with the inter-group variation as close to zero as possible, and, at the same time, having the smallest errors bars possible [51]. A change in the indication of most stable genes was observed after NormFinder analysis when compared to geNorm, with $H 2 B$ showing the most stable 
Table 2 Primer sequences and amplicon characteristics for each of the 11 reference genes and for the Argonaute 1 gene of interest

\begin{tabular}{|c|c|c|c|c|}
\hline $\begin{array}{l}\text { Gene } \\
\text { symbol }\end{array}$ & $\begin{array}{c}\text { Primer sequence }\left(5^{\prime} \rightarrow 3^{\prime}\right) \\
\text { Forward/Reverse }\end{array}$ & $\begin{array}{l}\text { Amplicon } \\
\text { length (bp) }\end{array}$ & $\begin{array}{c}\text { Annealing } \\
\text { temperatures } \\
\left({ }^{\circ} \mathrm{C}\right)\end{array}$ & $\begin{array}{c}\text { Amplification } \\
\text { efficiency }\end{array}$ \\
\hline 185 & $\begin{array}{l}\text { TGACGGAGAATTAGGGTTCG/ } \\
\text { CCGTGTCAGGATTGGGTAAT }\end{array}$ & 100 & 60 & 1.860 \\
\hline ACT2 & $\begin{array}{l}\text { TCCACCATGTTCCCTGGTAT/ } \\
\text { ACCTCCCAATCCAGACACTG }\end{array}$ & 124 & 60 & 1.935 \\
\hline EF2 & $\begin{array}{l}\text { GCGTTCCCTCAGTGTGTCTT/ } \\
\text { GGTCATCTGCTCCTTCAAGC }\end{array}$ & 126 & 60 & 1.790 \\
\hline EUC12 & $\begin{array}{l}\text { GCGTGGTTCTTGGATCACTA/ } \\
\text { TGGTGACAAAGTCAGGTGCT }\end{array}$ & 114 & 59 & 1.807 \\
\hline$H 2 B$ & $\begin{array}{c}\text { GAAGAAGCGGGTGAAGAAGA/ } \\
\text { GGCGAGTTTCTCGAAGATGT }\end{array}$ & 145 & 60 & 1.972 \\
\hline $\mathrm{IDH}^{*}$ & $\begin{array}{l}\text { CTGTTGAGTCTGGAAGATGAC/ } \\
\text { CATTTAATCCTCCCCAACAAA }\end{array}$ & 271 & 60 & 1.892 \\
\hline$U B I$ & $\begin{array}{c}\text { AGAAGGAATCGACCCTCCAC/ } \\
\text { CCTTGACGTTGTCAATGGTG }\end{array}$ & 126 & 60 & 1.888 \\
\hline SAND & $\begin{array}{l}\text { CCATTCAACACTCTCCGACA } \\
\text { TGTGTGACCCAGCAGAGTAAT }\end{array}$ & 143 & 59 & 1.919 \\
\hline TIP41 & $\begin{array}{l}\text { GAACAAAAGCTCGGGACATC/ } \\
\text { CAACCAGCAAGAGCATCAAA }\end{array}$ & 122 & 60 & 1.938 \\
\hline TUA & $\begin{array}{l}\text { ACCGGTTGATCTCTCAGGTG/ } \\
\text { TAAGGGACCAGGTTGGTCTG }\end{array}$ & 103 & 60 & 1.845 \\
\hline 33380 & $\begin{array}{l}\text { TCCAGAGTGCAATGCTGAAC/ } \\
\text { CCCCTCGTCTGGCATACTTA }\end{array}$ & 134 & 60 & 1.935 \\
\hline AGO1 & $\begin{array}{l}\text { TCTTGGGCTCGTTTCTCAGT } \\
\text { GGAATTCGCCTAGACAGTGC }\end{array}$ & 144 & 60 & 1.887 \\
\hline
\end{tabular}

* Primer obtained from Carvalho et al. (2008) [55].

expression (near zero variation value and small error bars), followed by TUA. These two genes were also among the most stably expressed genes based on geNorm analysis, displaying $M$ values below 0.5 (Figure 3 ). $U B I$ and $18 S$ were the least stable genes (both with variation values farther from zero and larger error bars) (Table 3). When defining the best combination of two genes using NormFinder, once again both $H 2 B$ and TUA were the genes of choice, with a stability value of 0.045 when used together (data not show).

\section{Relative expression profile of $A G O 1$}

To further validate the control genes and for determining the best choice of genes to use, the relative expression of a putative ortholog of A. thaliana ARGONAUTE1 (AGO1) gene in E. globulus was investigated during rooting. $A G O 1$ encodes a micro RNA binding protein [58] involved in regulating the expression of ARF17 (Auxin Response Factor 17), an auxin response transcription factor with inhibitory action, possibly controling genes related to auxin homeostasis and adventitious root development in A. thalina [10]. The two gene pairs indicated by geNorm and Normfinder were used as references to evaluate $A G O 1$ relative expression in eight samples, covering time points of adventitious root induction and formation, both under presence and absence of auxin during the induction step.

Using $I D H$ and $S A N D$ as references (indicated by geNorm) AGO1 relative expression profile was not significantly different among the adventitious rooting time points analysed both in presence or absence of auxin (Figure $5 \mathrm{~A}$ ). When $H 2 B$ and TUA were used as references (indicated by NormFinder), AGO1 relative expression at $48 \mathrm{~h}$ after transfer to formation step (48 $\mathrm{h}$ form) was significantly higher in absence of auxin (control), whereas no differences were detected for the auxin exposure treatment (Figure 5B). Moreover, when comparing presence and absence of auxin within each time point, $A G O 1$ relative expression after $48 \mathrm{~h}$ of culture on root induction medium ( $48 \mathrm{~h}$ ind) and at $24 \mathrm{~h}$ after transfer to root formation medium (24 $\mathrm{h}$ form) was higher in absence of auxin (control) than in presence of auxin (Figure 5B). Thus, the control gene combinations suggested by each program yielded different relative expression profiles of a gene of interest.

\section{Discussion}

In gene expression studies, qPCR is often the method of choice for a target gene expression profile investigation 

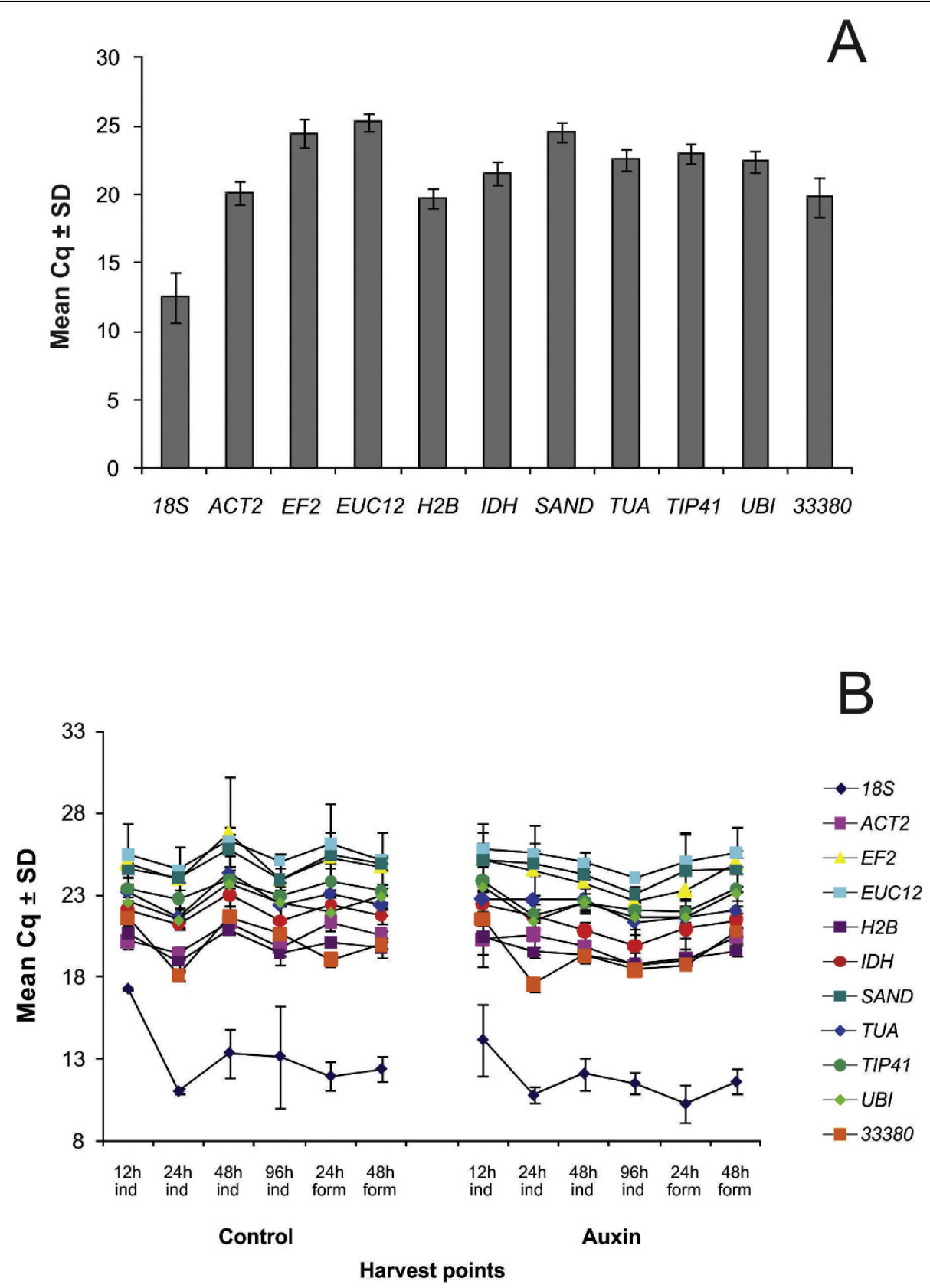

Figure 2 RNA transcription level of reference genes tested, presented as Cq mean value \pm Standard Deviation (SD). (A) Mean Cq of each reference gene. (B) Transcription level profile of reference genes along the adventitious rooting process. ind: induction step; form:

formation step. Auxin: indicates addition of $10 \mathrm{mg} \mathrm{I}^{-1}$ Indol Butyric Acid (IBA) in induction step culture medium; control: indicates absence of IBA in induction step culture medium.

because it is currently one of the most sensitive techniques available $[15-17,20]$. In this context, a correct normalization is a pre-requisite for the reliability of the final results $[59,60]$, especially considering possible biological relevance of small differences in gene expression or in the study of different tissues and organ samples [18].
In the present work, candidate reference genes for expression studies on adventitious rooting in E. globulus microcuttings were selected based on previous reports of normalization in plants, mainly with A. thaliana, Populus sp. and Eucalyptus sp., taking into account the model plant status of the first species and the woody habit of the last two genera. Additional genes frequently 


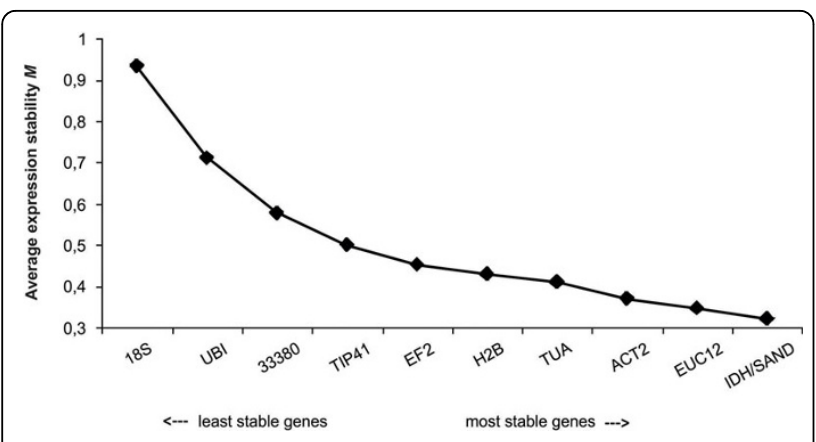

Figure 3 Gene expression stability $(M)$ and ranking of the 11 reference genes as calculated by geNorm in Eucalyptus globulus microcuttings during in vitro adventitious rooting. The microcuttings were rooted in presence or absence of $10 \mathrm{mg} \mathrm{l}^{-1}$ Indol Butyric Acid (IBA) in the induction step. A lower average expression stability $M$ value indicates more stable expression.

used for normalization in qPCR studies in other plant species were also evaluated.

The use of a single reference gene has been avoided to minimize the chances of erroneous expression estimates $[24,57]$. In fact, the use of multiple reference genes is becoming the golden standard in expression studies [19]. In order to select the most suitable reference genes for use in adventitious rooting, we investigated the relative expression profile of a gene of interest (AGO1) during this process, using the pairs of reference genes indicated as most stable by each one of the programs (geNorm and NormFinder).

An increase in $A G O 1$ expression would be expected during microcutting root development considering its function in regulating auxin metabolism-related genes during adventitious rooting in Arabidopsis [10]. The higher AGO1 expression in the absence of auxin may be

Table 3 Ranking of candidate reference genes in decreasing order of expression stability calculated by geNorm and NormFinder

\begin{tabular}{|c|c|c|}
\hline Ranking order & $\begin{array}{l}\text { geNorm } \\
\text { (M value) }\end{array}$ & $\begin{array}{c}\text { NormFinder } \\
\left.\text { (Stability value } \pm \mathrm{EB}^{*}\right)\end{array}$ \\
\hline 1 & IDH/SAND (0.320) & $H 2 B(0.031 \pm 0.006)$ \\
\hline 2 & & TUA $(0.084 \pm 0.067)$ \\
\hline 3 & EUC12 (0.346) & $\mathrm{IDH}(0.116 \pm 0.082)$ \\
\hline 4 & ACT2 (0.370) & $\operatorname{EUC12}(0.121 \pm 0.087)$ \\
\hline 5 & TUA (0.410) & $\operatorname{TIP} 41(0.123 \pm 0.091)$ \\
\hline 6 & $H 2 B(0.429)$ & $\operatorname{SAND}(0.143 \pm 0.124)$ \\
\hline 7 & $E F 2(0.452)$ & $33380(0.161 \pm 0.156)$ \\
\hline 8 & TIP41 (0.500) & $E F 2(0.174 \pm 0.183)$ \\
\hline 9 & $33380(0.579)$ & ACT2 $(0.186 \pm 0.215)$ \\
\hline 10 & UBI (0.712) & UBI $(0.306 \pm 0.566)$ \\
\hline 11 & $185(0.935)$ & $18 \mathrm{~S}(0.547 \pm 1.833)$ \\
\hline
\end{tabular}

${ }^{*} \mathrm{~EB}=$ Error Bars

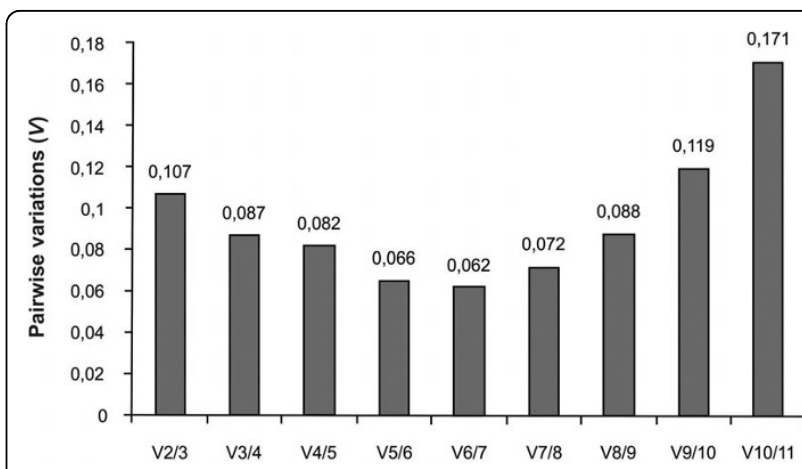

Figure 4 Determination of the optimal reference gene number as calculated by geNorm for accurate normalization during Eucalyptus globulus in vitro adventitious rooting. geNorm pairwise variation values ( $V$ values) are calculated by an algorithm which measures pairwise variation $(V n / n+1)$ between two sequential normalization factors NFn and NFn +1 , where $n$ is the number of genes involved in the normalization factor.

due to a lower requirement for the regulation of auxinmetabolism related genes in presence of exogenous auxin.

Therefore, NormFinder seemed to be better suited for the selection of the most stable reference genes for monitoring gene expression during adventitious rooting, detecting subtle differences that can be regarded as important for the adventitious rooting process. Recent studies have reported some discrepancies between different approaches for selection of reference genes and have chosen NormFinder $[43,45,61,62]$ as data analysis tool. This is mainly due to the wide applicability of this tool in any kind of experimental design, especially when involving different cell types and experimental stages associated with high variation of gene expression [45,51]. Hence, we suggest $H 2 B$ and TUA as the most adequate reference genes for expression studies during the rooting of E. globulus microcuttings.

$H 2 B$ (Histone $\mathrm{H} 2 \mathrm{~B}$ ) is one of the four core histones that form the mononucleosome, the fundamental repeating unit of chromatin in eukaryotic cells [63], being a key component for genetic material structure [52]. Two works have motivated us to include $H 2 B$ in our analysis. Hays et al. [64] employed it as reference in Northern blot analysis to assess differential gene expression between alfalfa (Medicago sativa L.) varieties exhibiting long- or short-stalked glandular hairs. Later, Sterky et al. [65], through a transcriptomics approach, showed that transcripts for histones (and ribosomal proteins) were among the most ubiquitous gene products present in different tissues and species of Populus. More recently, a histone $\mathrm{H} 3$ gene was included when defining reference genes for the analysis of gene expression in longan tree somatic embryogenesis by qPCR [45]. Nevertheless, histone genes have been employed as 
A

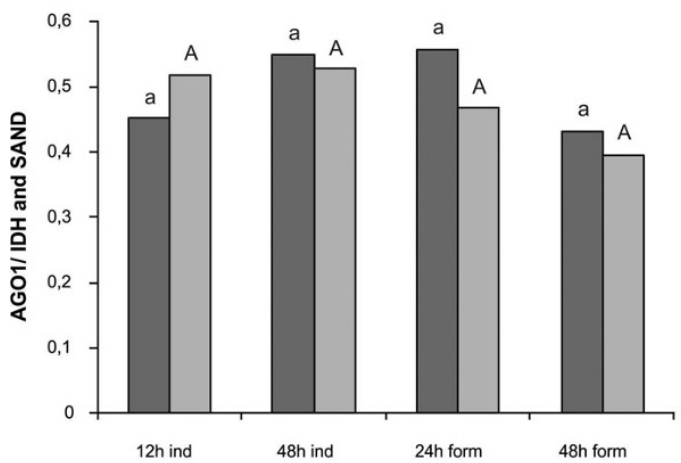

B

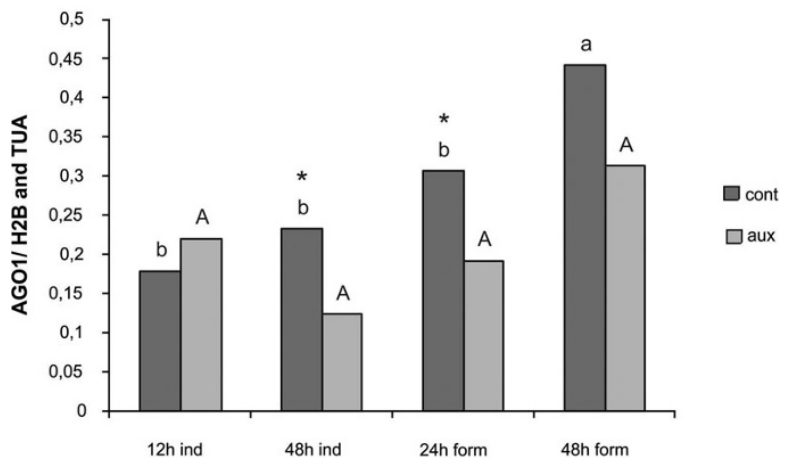

Figure 5 AGO1 relative expression profile during Eucalyptus globulus in vitro adventitious rooting. The AGO1 (Argonaute 1) expression profile was investigated relative to the best combination of reference genes indicated by both geNorm (A) and NormFinder (B) programs. Aux: indicates addition of $10 \mathrm{mg} \mathrm{l}^{-1}$ Indol Butyric Acid (IBA) in induction step culture medium; cont: indicates absence of IBA in induction step culture medium; Columns sharing the same letter are not different by ANOVA followed by Duncan test $(P \leq$ 0.05); small letters correspond to analysis of variance (ANOVA) performed for control treatment samples; capital letters correspond to analysis of variance (ANOVA) performed for samples treated with auxin. *: indicates significant difference between treatments within time points by t-test $(P \leq 0.05)$.

references mostly for expression studies in animal systems [66,67].

The high expression stability showed in our experiments for TUA corroborates data of Brunner et al. [24] in a study with poplar. On the other hand, Tong and collaborators found TUA as one of the most variable genes for studies with peach, except when comparing genotypes or different storage time of fruit [40].

Data to date point to $I D H$ as the most used control gene for normalization in Eucalyptus sp. [53-55], but without indication of a previous reference-gene detailed analysis. Although elected as the most stably expressed gene in Eucalyptus clones under biotic and abiotic stress
[50], results from the present study did not support ranking $I D H$ as one of the best reference genes because, together with SAND, it appears less sensitive to detect slight differences in the expression profile of an adventitious rooting-related gene of interest. This fact reinforces the need of detailed reference gene analysis for specific experimental conditions and processes.

Adventitious rooting is a very complex process, regulated by both environmental and endogenous factors, but the molecular mechanisms by which adventitious root formation is regulated are still poorly understood. Important advances are upcoming with genetic and microarray studies in Populus, especially after the availability of the poplar genome [68]. Studying gene expression during rooting in Pinus contorta, Brinker et al. [69] reported an increased expression of genes involved in protein synthesis and a decreased expression of genes related to protein degradation for the first 3 days after auxin treatment, whereas an opposite trend was observed during root formation and elongation. Sorin $e t$ $a l$. also identified proteins with altered expression during adventitious rooting in Arabidopsis mutants, and, among these, there were some related to protein degradation [70]. These observations may help explain the low expression stability of the gene for polyubiquitin $(U B I)$ found in our experiments (Figure 3 and Table 3), since the product of this gene is known to function in protein degradation [71].

The least stably expressed gene was $18 \mathrm{~S}$, both by geNorm and NormFinder analysis (Figure 3 and Table 3). The use of rRNA as reference gene was previously considered a good strategy in gene expression studies [21] but recent works suggest that this is often not the case $[24,72,29,40,44,45]$. This is possibly due to the high abundance of $18 S$ rRNA compared with target mRNA transcripts, making it difficult to accurately subtract the baseline value in qPCR data analysis [24]. Besides, $18 \mathrm{~S}$ rRNA can not be used for this purpose when reverse transcription is carried out using oligo-dT primers or only mRNA is used as template [29].

The most stably expressed genes identified in this study, $H 2 B$ and TUA, were effective references in both phases of the rooting process, induction and formation, and also in presence or absence of auxin, i.e. with conditions leading to profuse and scarce root development, respectively (Figure $2 \mathrm{~B}$ and Figure $5 \mathrm{~B}$ ). This is a rather important feature because it allows the use of these genes as internal controls in evaluating the expression of putative key genes in the rooting process that are likely to vary between phases and in conditions leading or not to root development [73]. These key genes may include those encoding auxin transporters, auxin metabolism enzymes, auxin receptors and selective proteolysis-related proteins [74]. 


\section{Conclusions}

This work constitutes the first in-depth study to validate optimal control genes for the quantification of transcript levels in E. globulus during in vitro adventitious rooting.

Considering that both programs used are based on distinct statistical algorithms, potential discrepancies could be expected. The comparative AGO1 expression profile, using the combinations of reference genes indicated by each program, allowed us to suggest the most adequate combination of control genes, based on the functions described in the literature for this gene of interest. Hence, the NormFinder program was considered more appropriate for our experiments, indicating $H 2 B$ and TUA as suitable reference genes for normalization in E. globulus microcuttings rooted in vitro. Besides, $U B I$ and $18 S$ are not indicated for use as internal controls in this species under the conditions tested.

In summary, these findings represent useful tools for normalization of qPCR results and will enable more accurate and reliable gene expression studies related to the vital process of clonal propagation by rooting in this important woody species.

\section{Methods}

\section{Plant material}

Seeds of Eucalyptus globulus Labill (batches from Chile and kindly supplied by Celulose Riograndense S.A., Guaíba, RS, Brazil) were surface-sterilized in $70 \%(\mathrm{v} / \mathrm{v})$ ethanol (1 min) and 1.5\% (v/v) $\mathrm{NaClO}(20 \mathrm{~min})$ followed by 4 washes in sterile distilled water. Fifteen seeds were planted in $300 \mathrm{ml}$ glass flasks (capped with a double layer of aluminum foil) containing $60 \mathrm{ml}$ of medium as follows: half-strength modified MS salts [75] with the concentration of calcium chloride reduced to $1 / 6,2 \%$ $(\mathrm{w} / \mathrm{v})$ sucrose, $\mathrm{pH}$ adjusted to $5.8 \pm 1$ and $0.6 \%(\mathrm{w} / \mathrm{v})$ agar (extra pure microbiological grade, Merck) [8]. The medium was sterilized in autoclave for $20 \mathrm{~min}$ at $121^{\circ} \mathrm{C}$. The growth room conditions were $16 \mathrm{~h}$ photoperiod, 30 $\mu \mathrm{mol} \mathrm{m} \mathrm{m}^{-2}$ of photosynthetically active radiation (provided by white light fluorescent tubes) and temperature of $23 \pm 2^{\circ} \mathrm{C}$. After 14 weeks, tip microcuttings (about 3 $\mathrm{cm}$ in length) were excised from the seedlings and used for in vitro rooting experiments.

\section{In vitro adventitious rooting experiments}

The culture system consisted of a two-step protocol: an initial step of induction, which lasted $96 \mathrm{~h}$ (induction medium composition: $0.3 \mathrm{x}$ MS salt concentration, 0.4 $\mathrm{mg} \mathrm{l}^{-1}$ thiamine $\mathrm{HCl}, 100 \mathrm{mg} \mathrm{l}^{-1}$ inositol, zero (control) or $10 \mathrm{mg} \mathrm{l}^{-1}$ indolyl-butyric acid (leading to rooting), equivalent to $49.3 \mu \mathrm{M}, 30 \mathrm{~g} \mathrm{l}^{-1}$ sucrose and $6 \mathrm{~g} \mathrm{l}^{-1}$ agar, adjusted to $\mathrm{pH} 5.8 \pm 1$ before autoclaving), followed by a formation step (same composition of induction medium except without added auxin and supplemented with $1 \mathrm{~g} \mathrm{l}^{-1}$ activated charcoal) [8].

Experiments were carried out in $20 \mathrm{ml}$ glass vials containing $6 \mathrm{ml}$ of medium, which were capped with a double layer of aluminum foil, at a density of two explants per vial. Both treatments (presence and absence of auxin during the induction step) were carried out in a growth room with the same conditions described above for seed germination.

The expression analysis of the selected genes was monitored along the rooting process and the harvest of microcuttings for RNA extraction was at 12, 24, 48 and $96 \mathrm{~h}$ of exposure to induction medium and 24 and $48 \mathrm{~h}$ after transfer to formation medium (formation step), for both treatments (with and without auxin in the first step). For the formation step harvest, the microcuttings remained for $96 \mathrm{~h}$ in the induction medium before transfer to formation medium (see Figure 1 for details). The microcuttings were immediately frozen in liquid nitrogen and stored at $-80^{\circ} \mathrm{C}$ until RNA extraction. Each point of harvest combined six microcuttings (approximately $200 \mathrm{mg}$ of homogenized tissue fresh weight). The experimental design was completely randomized and the experiments were independently repeated three times with similar results.

\section{Total RNA extraction and first strand CDNA synthesis}

Total RNA was isolated using NucleoSpin RNA Plant Kit (Macherey-Nagel) including DNAse I treatment, following the manufacturer recommendations, with modifications as follows: $200 \mathrm{mg}$ of homogenized tissue fresh weight from each sample was divided in two fractions of $100 \mathrm{mg}$. Each fraction of $100 \mathrm{mg}$ had its RNA extracted separately. After the extraction procedure, the corresponding fractions were joined again for RNA quantification. Total RNA concentration was determined using Quant-iT ${ }^{\mathrm{mx}}$ RNA Assay Kit and the Qubit fluorometer (Invitrogen) and quality was monitored by electrophoresis in 1\% agarose gel (data not show). One independent cDNA synthesis was performed for all of the samples starting from $100 \mathrm{ng}$ total RNA. First strand cDNA synthesis was performed using oligo-dT primers and reverse transcriptase M-MLV (Invitrogen) in a final volume of $20 \mu \mathrm{l}$. The final cDNA products were diluted 10 -fold in RNAse-free distilled water prior to use in qPCR.

\section{PCR primer design}

The sequences used to design the primer pairs, except $I D H$, whose primers were obtained from Carvalho et al. [55], represent putative orthologs in eucalypt of genes chosen for this study and are described in Table 1 . For that, sequences placed in the Arabidopsis thaliana 
Database (http://www.arabidopsis.org) were subjected to a tBlastx against the Genolyptus Project Database (http://www.lge.ibi.unicamp.br/eucalyptus/) and the sequence with highest homology was selected. For all genes, primer pairs were designed using Oligo Perfect ${ }^{\mathrm{TM}}$ Designer software (Invitrogen) and are described in Table 2. The specifications were: melting temperatures (Tm) of $58-62^{\circ} \mathrm{C}$, primer lengths of 20 nucleotides, guanine-cytosine contents of $45-55 \%$ and PCR amplicon lengths of 100-150 base pairs.

\section{qPCR conditions}

The qPCR analyses were performed in fast optical 48well reaction plates $0.1 \mathrm{ml}$ (MicroAmp ${ }^{\mathrm{Tm}}$ - Applied Biosystems) using a StepOne ${ }^{\mathrm{Tm}}$ Real-Time PCR System (Applied Biosystems) according to the manufacturer instructions. All of the reactions were carried out in quadruplicates for each cDNA sample and contained $10 \mu \mathrm{l} 10$-fold diluted cDNA template, $4.25 \mu$ sterile water, $2 \mu \mathrm{l} 10 \times$ PCR Buffer (Invitrogen), $1.2 \mu \mathrm{l}$ of $25 \mathrm{mM} \mathrm{MgCl}_{2}$ (Invitrogen), $0.1 \mu \mathrm{l}$ of $10 \mathrm{mM}$ dNTP (Invitrogen), $2 \mu \mathrm{l} \mathrm{SYBR}$ Green (1:10,000, Molecular Probes, Applied Biosystems), $0.2 \mu \mathrm{l}$ of each of the $10 \mu \mathrm{M}$ forward and reverse genespecific primers and $0.05 \mu$ l Platinum ${ }^{\odot}$ Taq DNA polymerase $(5 \mathrm{U} / \mu \mathrm{l}$, Invitrogen) in a final volume of $20 \mu \mathrm{l}$. This experiment was repeated three times in independent runs for all selected genes per time sample.

Reactions were incubated at $95^{\circ} \mathrm{C}$ for $5 \mathrm{~min}$ to activate the Platinum ${ }^{\oplus}$ Taq DNA polymerase (Invitrogen), followed by 40 cycles of $95^{\circ} \mathrm{C}$ for $15 \mathrm{sec}, 60^{\circ} \mathrm{C}$ for $10 \mathrm{sec}$, and $72^{\circ} \mathrm{C}$ for $15 \mathrm{sec}$. The specificity of the PCR was confirmed with a heat dissociation curve (or melting curve) from $60^{\circ} \mathrm{C}$ to $90^{\circ} \mathrm{C}$, following the final PCR cycle. This procedure allowed us to verify that the resulting fluorescence originated from a single PCR product and did not represent primer dimerization formed during PCR or a non-specific product.

\section{Determination of reference gene expression stability}

Two publicly available software tools, geNorm v. 3.5 [24] and NormFinder [51] were used to evaluate gene expression stability. Both tools require the transformation of $\mathrm{Cq}$ (quantification cycle) values to linear scale expression quantities. The $\mathrm{Cq}$ values were converted into relative quantities by the delta-Cq method [56] using the sample with the lowest $\mathrm{Cq}$ as calibrator and taking into account the amplification efficiencies for each primer pair obtained with LinReg PCR software [76]. The measures were then exported to Microsoft Excel.

\section{geNorm approach}

The geNorm software is a Visual Basic Application (VBA) tool for Microsoft Excel and relies on the principle that the expression ratio of two ideal reference genes should be constant throughout the different experimental conditions or cell types [24]. This program estimates an expression stability value $(M)$ for each gene, defined as the average pairwise variation of a certain gene with all other control genes in a given panel of cDNA samples. Genes with the lowest $M$ values have the most stable expression and an ideal $M$-value must be preferably $<0.5[57,27]$. Reference genes are ranked by geNorm through the elimination of the worst-scoring candidate control gene (the one with the highest $M$ value) and recalculating of new $M$ values for the remaining genes. At the end of this procedure, two candidate genes are always top-ranked because expression ratios are required for gene-stability measurements [24]. The geNorm program also allows the establishment of minimal number of control genes required for calculating an accurate normalization factor, as the geometric mean of their relative quantities. A pairwise variation of 0.15 is accepted as cut-off [24] below which the inclusion of an additional control gene is not required for reliable normalization.

\section{NormFinder approach}

The NormFinder software [51], another VBA applet, uses a model-based approach for identifying the optimal normalization gene(s) among a set of candidates. This strategy is based on a mathematical model of gene expression that enables estimation of the intra- and inter-group variations, which are combined into a stability value. Candidate control genes with the minimal intra-group variation will have the lowest stability value and will be top ranked [51]. For adequate application of the NormFinder program, the sample sets were subdivided in two groups (presence and absence of auxin in the induction step of adventitious rooting) with each of them containing 6 samples.

\section{Determination of $A G O 1$ expression profile}

The putative A. thaliana AGO1 ortholog in E. globulus had its expression profile investigated in eight samples among the twelve analyzed in this study (12 and $24 \mathrm{~h}$ after inoculation in induction medium, and 24 and $48 \mathrm{~h}$ after transfer to formation medium, both in presence and absence of auxin in induction medium). The experiment was carried out with three biological replicates and the qPCR method and primer design strategy followed the same parameters used for the analysis of reference genes. The relative expression profile analysis was obtained through the delta-Cq method [56]. Analysis of Variance (ANOVA), followed by Duncan's test when appropriate $(P \leq 0.05)$, were applied for samples of the same treatment (presence or absence of auxin). To compare the same time point of different treatments, a $t$-test was used $(P \leq 0.05)$. 


\section{List of abbreviations}

AGO1: Argonaute 1; AUX1: Auxin Resistant 1; PIN: Arabidopsis thaliana PINFormed proteins; GPCR: reverse-transcription followed by quantitative realtime Polymerase Chain Reaction; RNA: Ribonucleic Acid; PCR: Polymerase Chain Reaction; Cq: Quantification cycle; Tm: melting temperature; S.D: Standard Deviation; VBA: Visual Basic Application; NF: Normalization Factor; $\mathrm{NaClO}$ : Sodium Hypochloride; cDNA: complementary Deoxyribonucleic Acid.

\section{Authors' contributions}

MRA performed all the experimental procedures, data analysis and drafted the manuscript. CMR assisted on the execution of experimental procedures and data analysis. FKR and RAS helped designing primers and in data analysis. GP assisted in gene selection and sequence identification at the Genolyptus database. AGFN conceived and supervised the study and finalized the paper. All authors read and approved the final manuscript.

\section{Acknowledgements}

This research was funded by the Brazilian agencies National Council for Scientific and Technological Development (CNPq) and National Commission for Graduate Program Funding and Evaluation (CAPES). Seeds of E. globulus were a gift from Celulose Riograndense (Guaíba, RS, Brazil).

\section{Author details}

${ }^{1}$ Center for Biotechnology, Federal University of Rio Grande do Sul, P.O. Box 15005, 91501-970 Porto Alegre, RS, Brazil. ${ }^{2}$ Department of Botany, Federal University of Rio Grande do Sul, P.O. Box 15005, 91501-970 Porto Alegre, RS, Brazil.

Received: 5 April 2010 Accepted: 20 September 2010 Published: 20 September 2010

\section{References}

1. Del Lungo A, Ball J, Carle J: Global planted forests thematic study: results and analysis. Planted Forests and Trees Working Paper 38 FAO (Food and Agriculture Organization of the United Nations - Forestry Department) 2006.

2. Statistical yearbook from ABRAF. Brazilian Association of Foresters (Associação Brasileira de Produtores de Florestas Plantadas) 2009.

3. Mora AL, Garcia CH: The Eucalyptus Culture in Brazil (A Cultura do Eucalipto no Brasil). SBS, São Paulo 2000, 112

4. Chiang V: From rags to riches. Nat Biotechnol 2002, 20:557-558.

5. Le Roux JJ, Van Staden J: Micropropagation and tissue culture of Eucalyptus - a review. Tree Physiol 1991, 9:435-477.

6. Serrano L, Rochange F, Semblant JP, Marque C, Teulières C, Boudet AM: Genetic transformation of Eucalyptus globulus through biolistics: complementary development of procedures for organogenesis from zygotic embryos and stable transformation of corresponding proliferating tissue. J Exp Bot 1996, 45:285-290.

7. De Klerk GJ, Van Der Krieken W, De Jong JC: The formation of adventitious roots: New concepts, new possibilities. In Vitro Cell Dev-PI 1999, 35(3):189-199.

8. Fett-Neto AG, Fett JP, Goulart LWV, Pasquali G, Termignoni RR, Ferreira AG: Distinct effects of auxin and light on adventitious root development in Eucalyptus saligna and Eucalyptus globulus. Tree Physiol 2001, 21:457-464.

9. Ruedell CM, Schwambach J, Corrêa LR, Fett-Neto AG: Strategies for adventitious rooting in clonal propagation of Eucalyptus. In Adventitious root formation of forest trees and horticultural plants - From genes to applications. Edited by: Niemi K, Scagel C. Kerala: Research Signpost: 2009:337-358.

10. Sorin C, Bussell JD, Camus I, Ljung K, Kowalczyk M, Geiss G, Mckhann H, Garcion C, Vaucheret H, Sandberg G, Bellini C: Auxin and light control of adventitious rooting in Arabidopsis require ARGONAUTE 1. Plant Cell 2005, 17:1343-1359.

11. Fogaça CM, Fett-Neto AG: Role of auxin and its modulators in the adventitious rooting of Eucalyptus species differing in recalcitrance. Plant Growth Regul 2005, 45:1-10.

12. Muday GK, Delong A: Polar auxin transport: controlling where and how much. Trends Plant Sci 2001, 6:535-542.

13. Benjamins R, Scheres B: Auxin: the looping star in plant development. Annu Rev Plant Biol 2008, 59:443-465.

14. Li S-W, Xue L, Xu S, Feng H, An L: Mediators, genes and signaling in adventitious rooting. Bot Rev 2009, 75:230-247.
15. Bustin $S A$ : Quantification of mRNA using real-time reverse transcription PCR (RT-PCR): trends and problems. J Mol Endocrinol 2002, 29:23-39.

16. Ginzinger DG: Gene quantification using real-time quantitative PCR: An emerging technology hits the mainstream. Exp Hematol 2002, 30(6):503-512.

17. Gachon C, Mingam A, Charrier B: Real time PCR: what relevance to plant studies? J Exp Bot 2004, 55(402):1445-1454.

18. Huggett J, Dheda K, Bustin S, Zumla A: Real-time RT-PCR normalisation; strategies and considerations. Genes Immun 2005, 1-6.

19. Bustin SA, Benes V, Garson JA, Hellemans J, Huggett J, Kubista M, Mueller R, Nolan T, Pfaffl MW, Shipley GL, Vandesompele J, Wittwer CT: The MIQE Guidelines: Minimum Information for Publication of Quantitative RealTime PCR Experiments. Clin Chem 2009, 55(4):611-622.

20. Van Guilder HD, Vrana KE, Freeman WM: Twenty-five years of quantitative PCR for gene expression analysis. BioTechniques 2008, 44:619-626.

21. Thellin O, Zorzi W, Lakaye B, De Borman B, Coumans B, Hennen G, Grisar T, Igout A, Heinen E: Housekeeping genes as internal standards: use and limits. J Biotechnol 1999, 75:291-295.

22. Czechowski T, Stitt M, Altmann T, Udvardi MK, Scheible W: Genome-wide identification and testing of superior reference-genes for transcript normalization in Arabidopsis. Plant Physiol 2005, 139:5-17.

23. Schmittgen TD, Zakrajsek BA: Effect of experimental treatment on housekeeping gene expression: validation by real-time, quantitative RTPCR. J Biochem Bioph Meth 2000, 46:69-81.

24. Vandesompele J, De Preter K, Pattyn F, Poppe B, Van Roy N, De Paepe A, Speleman F: Accurate normalisation of real-time quantitative RT-PCR data by geometric averaging of multiple internal control genes. Genome Biol 2002, 3:1-11.

25. Brunner AM, Yakovlev IA, Strauss SH: Validating internal controls for quantitative plant gene expression studies. BMC Plant Biol 2004, 4:14.

26. Nicot N, Hausman J, Hoffman L, Evers D: Housekeeping gene selection for real-time RT-PCR normalization in potato during biotic and abiotic stress. J Exp Bot 2005, 56(421):2907-2914.

27. Gutierrez L, Mauriat M, Guénin S, Pelloux J, Lefebvre J, Louvet R, Rusterucci C, Moritz T, Guerineau F, Bellini C, Van Wuytswinkel O: The lack of a systematic validation of reference genes: a serious pitfall undervalued in reverse transcription-polymerase chain reaction (RT-PCR) analysis in plants. Plant Biotechnol J 2008, 6:609-618.

28. Kim BR, Nam HY, Kim SU, Kim SI, Chang YJ: Normalization of reverse transcription quantitative-PCR with housekeeping genes in rice. Biotechnol Lett 2003, 25(21):1869-72.

29. Jain M, Nijhawan A, Tyagi AK, Khurana JP: Validation of housekeeping genes as internal control for studying gene expression in rice by quantitative real-time PCR. Biochem Bioph Res Co 2006, 345:646-651.

30. Iskandar HM, Simpson RS, Casu RE, Bonnett GD, Maclean DJ, Manner JM: Comparison of reference genes for quantitative real-time polymerase chain reaction analysis of gene expression in sugarcane. Plant Mol Biol Rep 2004, 22:325-337.

31. Remans T, Smeets K, Opdenakker K, Mathijsen D, Vangronsveld J, Cuypers A: Normalization of real-time RT-PCR gene expression measurements in Arabidopsis thaliana exposed to increased metal concentrations. Planta 2008, 227:1343-1349.

32. Reid KE, Olsson N, Schlosser J, Peng F, Lund ST: An optimized grapevine RNA isolation procedure and statistical determination of reference genes for real-time RT-PCR during berry development. BMC Plant Biol 2006, 6:27.

33. Faccioli P, Ciceri GP, Provero P, Stanca AM, Morcia C, Terzi V: A combined strategy of "in silico" transcriptome analysis and web search engine optimization allows an agile identification of reference genes suitable for normalization in gene expression studies. Plant Mol Biol 2007, 63:679-688.

34. Hong S, Seo PJ, Yang MS, Xiang F, Park CM: Exploring valid reference genes for gene expression studies in Brachypodium distachyon by realtime PCR. BMC Plant Biol 2008, 8:112.

35. Jian B, Liu B, Bi Y, Hou W, Wu C, Han T: Validation of internal control for gene expression study in soybean by quantitative real-time PCR. BMC Mol Biol 2008, 9:59.

36. Libault M, Thibivilliers S, Bilgin DD, Radwan O, Benitez M, Clough SJ, Stacey G: Identification of four soybean reference genes for gene expression normalization. Plant Genome 2008, 1:44-54.

37. Expósito-Rodríguez M, Borges AA, Borges-Pérez A, Pérez JA: Selection of internal control genes for quantitative real-time RT-PCR studies during tomato development process. BMC Plant Biol 2008, 8:131. 
38. Silveira ED, Alves-Ferreira M, Guimarães LA, Silva FR, Carneiro VTC: Selection of reference genes for quantitative real-time PCR expression studies in the apomictic and sexual grass Brachiaria brizantha. BMC Plant Biol 2009, 9:84.

39. Barsalobres-Cavallari CF, Severino FE, Maluf MP, Maia IG: Identification of suitable internal control genes for expression studies in Coffea arabica under different experimental conditions. BMC Molecular Biol 2009, 10:1.

40. Tong Z, Gao Z, Wang F, Zhou J, Zhang Z: Selection of reliable reference genes for gene expression studies in peach using real-time PCR. BMC Mol Biol 2009, 10:71.

41. Paolacci AR, Tanzarella OA, Porceddu E, Ciaffi M: Identification and validation of reference genes for quantitative RT-PCR normalization in wheat. BMC Mol Biol 2009, 10:11.

42. Maroufi A, Van Bockstaele E, De Loose M: Validation of reference genes for gene expression analysis in chicory (Cichorium intybus) using quantitative real-time PCR. BMC Mol Biol 2010, 11:15.

43. Artico S, Nardeli SM, Brilhante O, Maria Grossi-de-Sá F, Alves-Ferreira M: Identification and evaluation of new reference genes in Gossypium hirsutum for accurate normalization of real-time quantitative RT-PCR data. BMC Plant Biol 2010, 10:49.

44. Wan H, Zhao Z, Qian C, Sui Y, Malik AA, Chen J: Selection of appropriate reference genes for gene expression studies by quantitative real-time polymerase chain reaction in cucumber. Anal Biochem 2010, 399:257-261.

45. Lin YL, Lai ZX: Reference gene selection for $\mathrm{qPCR}$ analysis during somatic embryogenesis in longan tree. Plant Science 2010, 178:359-365.

46. Mallona I, Lischewski S, Weiss J, Hause B, Egea-Cortines M: Validation of reference genes for quantitative real-time PCR during leaf and flower development in Petunia hybrida. BMC Plant Biol 2010, 10:4.

47. Lee JM, Roche JR, Donaghy DJ, Thrush A, Sathish P: Validation of reference genes for quantitative RT-PCR studies on gene expression in perennial ryegrass (Lolium perenne L.). BMC Mol Biol 2010, 11:8.

48. Wu G, Zhang L, Wu Y, Cao Y, Lu C: Comparison of five endogenous reference genes for specific PCR detection and quantification of Brassica napus. J Agric Food Chem 2010, 58:2812-2817.

49. Schmidt GW, Delaney SK: Stable internal reference genes for normalization of real-time RT-PCR in tobacco (Nicotiana tabacum) during development and abiotic stress. Mol Genet Genomics 2010, 283:233-241.

50. Boava LP, Laia ML, Jacob TR, Dabbas KM, Gonçalves JF, Ferro JA, Ferro MIT, Furtado EL: Selection of endogenous genes for gene expression studies in Eucalyptus under biotic (Puccinia psidii) and abiotic (acibenzolar-Smethyl) stresses using RTqPCR. BMC Res Notes 2010, 3:43.

51. Andersen $C L$, Jensen $J L$, Orntoft TF: Normalization of real-time quantitative reverse transcription-PCR data: A model-based variance estimation approach to identify genes suited for normalization, applied to bladder and colon cancer data sets. Cancer Res 2004, 64:5245-5250.

52. Campos El, Reinberg D: Histones: annotating chromatin. Annu Rev Genet 2009, 43:559-99.

53. Goicoechea M, Lacombe E, Legay S, Mihaljevic S, Rech P, Jauneau A, Lapierre C, Pollet B, Verhaegen D, Chaubet-Gigot N, Grima-Pettenati J: EgMYB2, a new transcriptional activator from Eucalyptus xylem, regulates secondary cell wall formation and lignin biosynthesis. Plant Journal 2005, 43:553-567.

54. Legay $S$, Lacombe E, Goicoechea M, Brièrea C, Séguind A, Mackayc J, GrimaPettenati J: Molecular characterization of EgMYB1, a putative transcriptional repressor of the lignin biosynthetic pathway. Plant Sci 2007, 173(5):542-549.

55. Carvalho MCCG, Caldas DGG, Carneiro RT, Moon DH, Salvatierra GR, Franceschini LM, Andrade A, Celedon PAF, Oda S, Labate CA: SAGE transcript profiling of the juvenile cambial region of Eucalyptus grandis. Tree Physiol 2008, 28:905-919.

56. Livak KJ, Schmittgen TD: Analysis of relative gene expression data using real-time quantitative $P C R$ and the $2^{-\Delta \Delta} C T$ method. Methods 2001, 25:402-408.

57. Hellemans J, Mortier G, De Paepe A, Speleman F, Vandesompele J: qBase relative quantification framework and software for management and automated analysis of real-time quantitative PCR data. Genome Biol 2007, 8:19.

58. Chen X: Small RNAs and their roles in plant development. Annu Rev Cell Dev Biol 2009, 25:21-44.

59. Dheda K, Huggett JF, Chang JS, Kima LU, Bustin SA, Johnson MA, Rook GAW, Zumla A: The implications of using an inappropriate reference gene for real-time reverse transcription PCR data normalization. Anal Biochem 2005, 344:141-143.

60. Guénin S, Mauriat M, Pelloux J, Van Wuytswinkel O, Bellini C, Gutierrez L: Normalization of qRT-PCR data: the necessity of adopting a systematic, experimental conditions-specific, validation of references. J Exp Bot 2009, 60(2):487-493.

61. Pernot F, Dorandeu F, Beaup C, Peinnequin A: Selection of reference genes for real-time quantitative reverse transcription-polymerase chain reaction in hippocampal structure in a murine model of temporal lobe epilepsy with focal seizures. Journal of Neuroscience Research 2010, 88:1000-1008.

62. Steiger MG, Mach RL, Mach-Aigner AS: An accurate normalization strategy for RT-qPCR in Hipocrea jecorina (Trichoderma reesei). Journal of Biotechnology 2010, 145:30-37.

63. Chatterjee C, Muir TW: Chemical approaches for studying histone modifications. J Biol Chem 2010, 285:11045-11050.

64. Hays DB, Skinner DZ: Development of an expressed sequence tag (EST) library for Medicago sativa. Plant Sci 2001, 161:517-526.

65. Sterky F, Bhalerao RR, Unneberg P, Segerman B, Nilsson P, Brunner AM, Charbonnel-Campaa L, Lindvall JJ, Tandre K, Strauss SH, Sundberg B, Gustafsson P, Uhlén M, Bhalerao RP, Nilsson O, Sandberg G, Karlsson J, Lundeberg J, Jansson S: A Populus EST resource for plant functional genomics. P Natl Acad Sci USA 2004, 101:13951-13956.

66. Goossens K, Van Poucke M, Van Soom A, Vandesompele J, Van Zeveren A, Peelman $L$ : Selection of reference genes for quantitative real-time PCR in bovine preimplantation embryos. BMC Dev Biol 2005, 5:27.

67. Sindelka R, Ferjentsik $Z$, Jonák J: Developmental expression profiles of Xenopus laevis reference genes. Dev Dynam 2006, 235:754-758.

68. Busov V, Yordanov YS, Meilan R: Discovery of genes involved in adventitious root formation using Populus as a model. In Adventitious root formation of forest trees and horticultural plants - From genes to applications. Edited by: Niemi K, Scagel C. Kerala: Research Signpost; 2009:85-103.

69. Brinker M, Van ZyI L, Liu W, Craig D, Sederoff RR, Clapham DH, Von Arnold S: Microarray analyses of gene expression during adventitious root development in Pinus contorta. Plant Physiol 2004 135:1526-1539.

70. Sorin C, Negroni L, Balliau T, Corti H, Jacquemot M, Davanture M, Sandberg G, Zivy M, Bellini C: Proteomic analysis of different mutant genotypes of Arabidopsis led to the identification of 11 proteins correlating with adventitious root development. Plant Physiol 2006, 140:349-364.

71. Schrader EK, Harstad KG, Matouschek A: Targeting proteins for degradation. Nat Chem Biol 2009, 5:815-822.

72. Gonçalves S, Cairney J, Maroco J, Oliveira MM, Miguel C: Evaluation of control transcripts in real-time RT-PCR expression analysis during maritime pine embryogenesis. Planta 2005, 222:556-563.

73. Ludwig-Müller J: Molecular basis for the role of auxins in adventitious rooting. In Adventitious root formation of forest trees and horticultural plants - From genes to applications. Edited by: Niemi K, Scagel C. Kerala: Research Signpost; 2009:1-29.

74. Woodward AW, Bartel B: A receptor for auxin. Plant Cell 2005, 17:2425-2429.

75. Murashigue T, Skoog F: A revised medium for rapid growth and bioassay with tobacco tissue cultures. Physiol Plant 1962, 15:473-498.

76. Ramakers C, Ruijtera JM, Deprez RHL, Moorman AFM: Assumption-free analysis of quantitative real-time polymerase chain reaction (PCR) data. Neurosci Lett 2003, 339:62-66.

doi:10.1186/1471-2199-11-73

Cite this article as: de Almeida et al:: Reference gene selection for quantitative reverse transcription-polymerase chain reaction normalization during in vitro adventitious rooting in Eucalyptus globulus Labill. BMC Molecular Biology 2010 11:73. 